\title{
Adoption of International Financial Reporting Standards (IFRS) in Ghana and the Quality of Financial Statement Disclosures
}

\author{
Dr. Ben K. Agyei-Mensah \\ Associate professor, Solbridge international school of business, \\ Deajeon, South Korea \\ Email: bamensah@solbridge.ac.kr, Ph: +82 426308538
}

Received: October 29, 2013 Accepted: December 05, 2013 DOI: 10.5296/ijafr.v3i2.4489

\begin{abstract}
According to the IASB's IFRS framework, qualitative characteristics are the attributes that make the information provided in financial statements useful to others. This study was conducted to investigate the quality of financial reports before and after adopting IFRSs in Ghana, and also the influence of firm-specific characteristics which include firm size, profitability, debt equity ratio, liquidity and audit firm size on the quality of financial information disclosed by firms listed on the Ghana Stock Exchange.

The research was conducted through detailed analysis of the pre-official adoption period, (2006) and post adoption period, (2008) financial statements of the listed firms. Descriptive analysis was performed to provide the background statistics of the variables examined. This was followed by regression analysis which forms the main data analysis. The results of the quality of financial information disclosure mean of $76.80 \%$ (pre adoption) and $87.09 \%$ (post adoption) for the two years indicate that the quality of financial reports has improved significantly after adopting IFRSs. The study thus confirms that the implementation of IFRSs generally reinforce accounting disclosure quality. It also indicates listed firms' overwhelming compliance with the IASB's IFRS Framework.

The results of the multiple regression analysis show that company size, represented by net assets and Auditor type were found to be associated at a statistically significant level with the quality of financial information disclosed. With the improvement in the quality of the financial reports after adopting IFRS users are assured of useful information for financial decision-making.
\end{abstract}

Keywords: Quality of financial reports' disclosure, Firm-specific characteristics, International Financial Reporting Standards, Mandatory disclosure, Ghana 


\section{Macrothink}

International Journal of Accounting and Financial Reporting

ISSN 2162-3082

2013, Vol. 3, No. 2

\section{Introduction}

This study provides evidence on the quality of disclosure of information in annual reports of firms listed on the Ghana Stock Exchange before and after Ghana adopted the International Financial Reporting Standards (IFRS).

The objective of financial statements is to provide information about the financial position, performance and financial adaptability of an enterprise that is useful to a wide range of users in making economic decisions. The International Accounting Standards Board's (IASB) IFRS Framework states that; "The objective of financial statements is to provide information about the financial position, performance and changes in financial position of an entity that is useful to a wide range of users in making economic decisions",(IASB 2010). The statements prepared also show the results of the management's stewardship.

According to (Sloan 2001) the financial statement is the first source of independent and true communication about the performance of managers.

To be able to meet the needs of the users, the financial statements must not only comply with the International Financial Reporting Standards (IFRS), but also be of high quality.

The quality of financial reports is measured using four key qualitative characteristics of financial information embedded within the Framework for the Preparation and Presentation of Financial Statements issued by International Accounting Standards Board (IASB 2010). These qualitative characteristics are relevance, faithful representation, comparability and understandability. According to the (IASB 2010) relevance and faithful representation are the fundamental qualities, whilst comparability and understandability are enhancing qualities. The Framework states that the qualitative characteristics are the attributes that make the information provided in financial statements useful to users.

Accounting information has the quality of relevance when it makes a difference in a business decision; it provides information that has predictive value and has confirmatory value (IASB 2010).

Accounting information has the quality of faithful representation when it accurately depicts what really happened; nothing important has been omitted (i.e. complete); and is not biased toward one position or another (i.e. neutral) (IASB 2010).

An enhancing quality of the information provided in financial statements is that it should be presented in such a way that it is readily understandable by users, i.e. it should be presented in a clear and concise fashion (IASB 2010).

Another enhancing quality of accounting information is that of comparability. Users must be able to compare the financial statements of an enterprise over time to identify trends in its financial position and performance. Users must also be able to compare the financial statements of different enterprises to evaluate their relative financial position, performance and financial adaptability. Consistency is therefore required, (IASB 2010).

The key research questions of this study are: 
1. What is the quality of financial and non-financial information disclosures in the annual reports of Ghanaian listed companies before and after adopting IFRS?

2. What firm-specific factors influence the quality of financial and non-financial information disclosures in the annual reports of Ghanaian listed companies?

Publicly traded companies (i.e. companies listed on the stock market) are required to make more financial statement disclosure (compared to privately held companies) for the benefit of existing and potential investors. Since the accounting scandals of Enron and WorldCom, the regulatory bodies have focused on companies disclosing information about the relationship with their public audit firm to determine proper independence.

The International Accounting Standards (IAS) defines the minimum level of disclosure in corporate annual reports expected by regulatory forces and they are stated in distinct sections of each standard and prescribe what information should be presented in the financial statements.

Financial information disclosure is defined as the release of information concerning the economic performance, position or prospects particularly as measured in monetary terms (Gibbins et al. 1990).

Prior to the adoption of IFRS in Ghana, the Generally Accepted Accounting Principles used was the Ghana National Accounting Standards. The Ghana National Accounting Standards was partly based on pre-IFRS, International Accounting Standards and the UK accounting standards. In 2004, the World Bank conducted a review of accounting and auditing practices in Ghana which was presented in its Report on Observance of Standards and Codes. This was to "evaluate the weaknesses and strengths of the accounting and auditing requirements, and to review the reporting requirements against actual practices" (ROSC, 2004). One of the major weaknesses identified in the report was that, the Ghana National Accounting Standards was outdated and differ significantly with International Accounting Standards. The World Bank therefore recommended that Ghana should adopt the IFRS. Hence The Institute of Chartered Accountants' proclamation that all financial reports from 2007 onwards should comply with the IFRS.

(Fekete 2008) states that IFRS disclosure compliance literature can be considered as part of disclosure research. It is on the basis of this statement and the fact that The Chartered Institute of Chartered Accountants Ghana (ICAG) expects all companies in the country to comply with these regulations that this study is being undertaking to check whether Ghanaian companies are complying with the disclosure requirements of IAS 1. IAS 1 requires that an entity whose financial statements comply with IFRSs make an explicit and unreserved statement of such compliance in notes. Financial statements shall not be described as complying with IFRSs unless they comply with all the requirements of IFRSs (including interpretations) (IAS 1.16). The research therefore, investigated the quality of the financial reports before the adoption (2006) and after the adoption (2008) of IFRS in Ghana.

As (Baiman and Verrecchia 1996) put it, the provision of quality accounting disclosures would tend to enhance the efficiency of the stock market. Despite the importance of the 
quality of accounting disclosures in enhancing the efficiency of the stock market, it is surprising that no such research has been conducted in Ghana, a developing country with an emerging stock market. This study is therefore set to fill that vacuum. Thus a study into the quality of disclosure of financial and non-financial information in corporate financial reports in Ghana is not out of place.

\section{Empirical studies on the quality of disclosure of financial and non-financial information and development of hypotheses}

The first study conducted on disclosures was done by (Cerf 1961) when he examined 527 corporate annual reports against a disclosure index comprising thirty one information items. He found that level of disclosure was positively associated with corporate size and listing status but not with profitability.

Following closely after (Cerf 1961), (Singhvi 1967) also found that disclosure quality was associated with asset size, number of stockholders, rate of return, earnings margin, security price fluctuations, listing status and CPA firm.

Research in disclosure level and compliance with IAS began around the turn of the century with research conducted by (Tower et al. 1999), (Cairns 1999) and (El-Gazzar et al. 1999). The study that analyzed the factors influencing IAS compliance was done by (Street and Gray 2002). Using an international sample of 279 firms they tested several variables against the level of disclosure such as; listing status, company size, industry, type of auditor, profitability, notes to the accounts, country, and size of home stock market among others.

(Dumontier and Raffournier 1998) in their study on the use of IAS in Switzerland hypothesized that the adoption of IAS would lead to increased information disclosure. They found that there was a positive influence of size, internationality, listing status, auditor type and ownership diffusion on IAS usage.

(Street and Bryant 2000) on the other hand found that greater disclosure is associated with accounting policies footnote that specifically states that the financial statements are prepared in accordance with IAS and an audit opinion that states that International Standards on Auditing (ISA) were used when conducting the audit.

(Hope et al. 2006) found that countries with weaker investor protection mechanisms are more likely to adopt IFRS, and therefore concluded that IFRS represent a vehicle through which countries can improve investor protection and make their capital markets more accessible to foreign investors.

The extent and quality of disclosure in annual financial reports have been examined by writers such as (Choi 1973), (Cooke 1989, 1992), (Wallace 1988), and (Zarzeski 1996). (Zarzeski 1996) examined annual reports from seven countries to determine whether cultural and market forces correlate with levels of disclosure by the firms. (Iatridis and Valahi 2010) quoted (Lang and Lundholm 1993; Healy and Palepu 2001) as saying that the factors that appear to affect the quality and detail of accounting disclosure as being: firm size, industry sector, stock ownership, stakeholder interests, international exposure, investors' expectations 


\section{MInstitute Macrothink $_{\text {Int }}$}

International Journal of Accounting and Financial Reporting ISSN 2162-3082

and other key financial variables such as profitability, liquidity, financial leverage, and growth.

There are several theoretical frameworks that underpin the disclosure literature according to (Palmer 2006). The two main recurring theoretical explanations given in the literature are agency theory and political costs. (Beattie 2005) cited in (Palmer 2006) suggests that positive accounting theorists have sought to move on from explaining accounting policy choices to explaining voluntary disclosure choices, and many of the theoretical explanations for the relationship between the level of disclosure of financial information and corporate characteristics are grounded in positive accounting theory.

Other researchers like (Meckling 1976) have argued that agency theory provides a framework that link disclosure behavior to corporate governance. To them corporate governance mechanisms are introduced to control the agency problem and ensure that managers act in the interests of shareholders.

According to (Bushman and Smith 2001) the reduction of information asymmetry following the provision of voluntary accounting disclosures would tend to reduce the related agency and political costs, and lead to lower costs in issuing equity capital. From the literature review the following hypotheses will be tested in the study.

\section{Hypotheses}

\section{Liquidity}

Liquidity refers to a firm's ability to meet its short-term obligations when they fall due. (Cooke 1989) argued that the soundness of the firm as portrayed by high liquidity is associated with greater disclosure level. (Belkaoui-Raihi 1978) found no relationship between liquidity and disclosure level, (Wallace et al. 1994) on the other hand found a significant negative association between liquidity and disclosure level for unlisted Spanish companies. From the foregoing the following hypothesis can be developed:

H1: Liquidity is positively associated with the quality of financial and non-financial statement disclosure.

\section{Size}

Studies by (Wallace and Naser 19995); (Raffournier 1995); (Owusu-Ansah 1998) and (Alsaeed 2005) found a significant relationship between the size of a company and the level of disclosure. The explanations provided by these writers include the fact that larger firms have more expertise and financial resources to disseminate financial information as compared to small firms.

(Cooke 1993) on the other hand suggests that larger companies, requiring more funding than smaller companies, have a need to raise capital at the lowest cost, and to do this companies will increase their voluntary and compliance with mandated disclosures like is stated in IAS 1.

Based on the above findings the following hypotheses will be tested: 


\section{Mll Macrothink}

International Journal of Accounting and Financial Reporting ISSN 2162-3082 2013, Vol. 3, No. 2

H2: Company size is positively associated with the quality of financial and non-financial statement disclosure.

\section{Profitability}

A positive relationship between profitability and the level of disclosure has been found by a number of studies (Inchausti 1997; Wallace et al. 1994; Wallace and Naser 1995). These studies found that firms with high profitability would be more motivated to send good news to the market than firms with low profitability.

(Agyei-Mensah 2012) found that there is a positive correlation between profitability and level of disclosure of rural banks in the Ashanti Region of Ghana.

IAS1 requires more disclosure about the source of earnings (e.g. continuing, discontinuing, acquired operations, individually significant items, etc.). The implication is that firms that are not performing well are not likely to voluntarily abide by the requirements of IAS 1 . On the other hand firms that are doing well would be inclined to comply with IAS 1, in order to provide evidence of superior managerial ability (Iatridis and Valahi 2010).

Following from the above studies the following hypothesis would be tested:

\section{H3: Profitability is positively associated with the quality of financial statement disclosure.}

\section{Audit firm size}

Several studies have tested the relationship between the size of audit firm and the level of disclosure. (Wallace et al. 1994, 47) postulate that bigger accounting firms are "backed by the expertise of the international firms to which they affiliated" and that a "theory of association" exits, suggesting that the contents of annual reports "are not only audited but also influenced by auditors". However, different results reported by (Marston and Robson 1997) and (Owusu-Ansah 1998) that auditor size is not significant associated with level of disclosure. This leads to the fourth hypothesis of this study:

H4: Auditor type is positively associated with the quality of financial statement disclosure.

\section{Leverage}

Several studies have examined the association between the debt equity ratio and the level of disclosure (Malone et al. 1993; Hossain et al. 1994; Ahmed and Nicolls 1994; Jaggi \& Low, 2000). These studies found a positive relationship between the debt equity and the level of disclosure. Firms with high debt equity may have more incentives to disclose more financial information to suit the needs of their creditors. Such firms are therefore expected to be monitored more by financial institutions which drive them to disclose more than firms with low debt equity. From the above the following hypothesis will be tested:

H5: Leverage is positively associated with the quality of financial statement disclosure. 


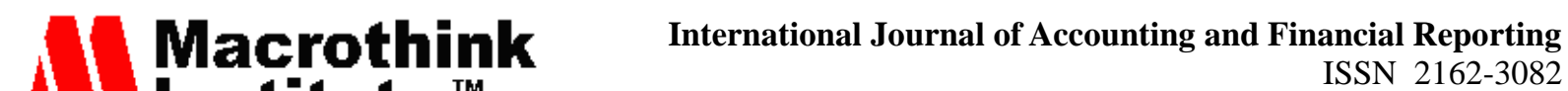 2013, Vol. 3, No. 2}

\section{Method}

\section{Data set and empirical methods}

The study focuses on the listed firms who have adopted IFRSs since the effective date for the adoption of IFRS, i.e. 2007. The sample consists of all the 35 listed firms on the Ghana Stock Exchange. All the sample firms adopted the IFRSs on the official adoption date. Accounting and financial data were collected from the GSE fact sheets and the firm's website. The empirical analysis concentrates on the pre-official adoption period, i.e. 2006 and the post-adoption period, i.e. 2008.

\section{Quality Financial Information Disclosure (QFID) Index}

The Quality of Financial Information Disclosure (QFID) Index measures the quality of financial information disclosure using the qualitative characteristics of financial information as advocated by the IASB's IFRS theoretical framework. Twenty key criteria, first used by (Beest, Braam, and Boelens, 2009), (see Appendix 2) based on IASB authoritative pronouncements are used to construct the quality index. This quality-oriented template comprises four elements of qualitative characteristics of the IASB's framework, include; relevance, faithful representation, comparability and understandability.

\section{Dependent variable}

The dependent variable of the study is the Quality of Disclosure (QOD) made by companies complying with IASB's IFRS qualitative characteristics of relevance, faithful representation, understandability and comparability. As noted earlier on IAS 1 specifies the disclosure that must be made, but the quality of the disclosure is likely to vary among the companies in the sample. Hence, the study focuses on all the mandatory and voluntary disclosure items and seeks to measure the quality of those disclosures for the listed firms.

A company was initially awarded a score of 1 if an item met the characteristic and 0 if an item did not meet the characteristic. The total number of items disclosed by a company was then divided by the expected total number of disclosure score of (20) and the result was used as the index of disclosure.

The disclosure index can be mathematically shown as follows;

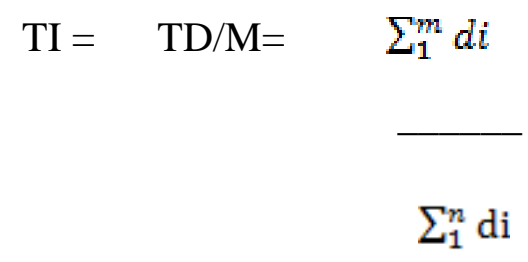

where:

$\mathrm{TI}=$ Total Disclosure Index

$\mathrm{TD}=$ Total Disclosure Score 
$\mathrm{M}=$ Maximum disclosure score for each company

$\mathrm{di}=$ Disclosure item $\mathrm{i}$

$\mathrm{m}=$ Actual number of relevant disclosure items $(\mathrm{m} \leq \mathrm{n})$

$\mathrm{n}=$ Number of items expected to be disclosed

\section{Independent variables measure}

To examine the quality of disclosure in accordance with IAS 1 and IASB's framework in the annual reports of the companies listed on the Ghana Stock Exchange (GSE) the following independent variables were tested: company size, leverage, profitability, liquidity and auditor type. The selection of the independent variables was based on the literature reviewed.

\section{Results}

\section{Quality of Disclosure}

Table .1 displays the industry classification of firms listed on the Ghana Stock Exchange (GSE). 31.4\% are from the Finance / Insurance category; 17.2\% from Manufacturing / Trading category; $14.3 \%$ from Paper conversion/Information Technology and Pharmacy / Beverages categories. $11.4 \%$ from Agric. / Agro processing and Metals and Oils categories.

Table 1: Industry classification of Ghana listed companies

\begin{tabular}{|l|l|l|}
\hline Industry Type & Frequency & Percentage (\%) \\
\hline Finance / Insurance & 11 & 31.4 \\
\hline Paper Conversion / IT & 5 & 14.3 \\
\hline Manufacturing / Trading & 6 & 17.2 \\
\hline Agric / Agro processing & 4 & 11.4 \\
\hline Metals / oils & 4 & 11.4 \\
\hline Pharmacy / Beverages & 5 & 14.3 \\
\hline TOTAL & 35 & 100 \\
\hline
\end{tabular}




\section{Macrothink}

International Journal of Accounting and Financial Reporting

Table 2: Auditor affiliation by industrial sector

\begin{tabular}{|l|l|l|l|}
\hline Industry & $\begin{array}{l}\text { Auditor affiliated } \\
\text { with international } \\
\text { auditing firm }\end{array}$ & $\begin{array}{l}\text { Auditor not affiliated } \\
\text { with international } \\
\text { auditing firm }\end{array}$ & Total \\
\hline Frequency $\%$ & Frequency $\%$ & 11 \\
\hline Finance and insurance & 11 & - & 5 \\
\hline Paper conversion/ IT & 2 & 3 & 6 \\
\hline Manufacturing/trading & 6 & - & 4 \\
\hline Agric/agro processing & 1 & 3 & 4 \\
\hline Metals/oils & 4 & - & 5 \\
\hline Pharmacy/Beverages & 5 & - & 6 \\
\hline TOTAL & 29 & $(7)$ & $35 \%)$ \\
\hline
\end{tabular}

From Table 2 above, $83 \%$ of the firms listed on the Ghana Stock Exchange are being audited by Audit firms with international affiliations.

From Table 3 below, the mean score for the quality disclosure index for the pre-official IFRS adoption period, 2006 is $60.61 \%$ and the maximum is $61 \%$, with a standard deviation of 0.0006592 . For the post IFRS adoption period, 2008 the mean is $87.09 \%$ and maximum of $95.24 \%$ and a standard deviation of $5.62 \%$. The results of the quality of disclosure level, mean of $87.09 \%$, for 2008 indicate a significant improvement in the quality of financial reports after adopting IFRS in 2007. It also indicates that most of the firms listed on the Ghana Stock Exchange are not only overwhelmingly complying with the IAS 1 disclosure requirements but also satisfying the IASB's IFRS qualitative characteristics of relevance, faithful representation, understandability, and comparability 


\section{Mll Macrothink \\ International Journal of Accounting and Financial Reporting \\ ISSN 2162-3082 \\ 2013, Vol. 3, No. 2}

Table 3: Disclosure Index (2006 and 2008)

\begin{tabular}{|r|r|r|r|r|r|}
\hline \multicolumn{1}{|c|}{ YEAR } & \multicolumn{1}{|l|}{ N } & \multicolumn{1}{l|}{ MIN } & \multicolumn{1}{l|}{ MAX } & \multicolumn{1}{l|}{ MEAN } & \multicolumn{1}{c|}{ SD } \\
\hline 2006 & 35 & 0.7061 & 0.8100 & 0.76805 & 0.000659 \\
\hline 2008 & 35 & 0.7619 & 0.9524 & 0.870949 & 0.562126 \\
\hline
\end{tabular}

A regression analysis was performed on the dependent and independent variables to check on the existence of the multi-colinearity problem. In a multiple regression model, multicollinearity exists when two independent variables are perfectly correlated with each other. The result is shown in the Table 4 below.

Table 4: Multiple regression analysis results ( multi-colinearity check)

Coefficients(a

\begin{tabular}{|c|c|c|c|c|c|c|c|c|}
\hline \multirow[t]{2}{*}{ Model } & & \multicolumn{2}{|c|}{ Unstandardized Coefficients } & \multirow{2}{*}{$\begin{array}{l}\text { Standardized } \\
\text { Coefficients } \\
\text { Beta }\end{array}$} & \multirow[t]{2}{*}{$\mathrm{t}$} & \multirow[t]{2}{*}{ Sig. } & \multicolumn{2}{|c|}{ Collinearity Statistics } \\
\hline & & B & Std. Error & & & & Tolerance & VIF \\
\hline \multirow[t]{6}{*}{1} & (Constant) & 0.641 & 0.048 & & 13.232 & 0.000 & & \\
\hline & $\begin{array}{l}\text { RETURN ON } \\
\text { CAPITAL } \\
\text { EMPLOYED }\end{array}$ & -0.001 & 0.001 & -0.306 & -1.667 & 0.106 & 0.808 & 1.237 \\
\hline & $\begin{array}{l}\text { DEBT EQUITY } \\
\text { RATIO }\end{array}$ & 0.010 & 0.010 & 0.170 & 0.933 & 0.358 & 0.822 & 1.216 \\
\hline & AUDITOR & -0.006 & 0.047 & -0.024 & -0.137 & 0.892 & 0.887 & 1.128 \\
\hline & NET ASSETS & $-2 \mathrm{E}-07$ & 0.000 & -0.222 & -1.271 & 0.214 & 0.893 & 1.120 \\
\hline & LIQUIDITY & 0.057 & 0.056 & 0.184 & 1.019 & 0.316 & 0.835 & 1.197 \\
\hline
\end{tabular}

a

Dependent Variable: QUALITY OF DISCLOSURE

The variable inflation factor (VIF) in excess of 10 should be considered an indication of harmful multi-colinearity according to Neter et al. (1989). All the VIF are less than 10 and the average VIF is 1.1796 therefore, it can be said that there is no multi-colinearity problem for the model. The results of the regression analysis can therefore be interpreted with a greater degree of confidence. The Durbin-Watson value of 1.723 (Table 5 below) indicates that the data has no serial correlation or autocorrelation problem. The multiple regression model is highly significant $(\mathrm{p} \leq 0.000)$. The coefficient of determination $\left(\mathrm{R}^{2}\right)$ indicates that 
$14.1 \%$ of the variation in dependent variable is explained by variation in the independent variables.

In order to test the specified hypotheses the stepwise method was used. The great advantage that this method has is that, it optimizes the econometric model so that all statistically non-significant variables are eliminated from the model.

The results of the multiple regression analysis shown in Tables 5, 6 and 7 below, show that type of auditor and firm size (represented by Net Assets) are associated on a statistically significant level as far as the quality of disclosure is concerned.

Table 5 : Model Summary(c)

\begin{tabular}{|l|r|r|r|r|r|}
\hline Model & $\mathrm{R}$ & R Square & $\begin{array}{c}\text { Adjusted R } \\
\text { Square }\end{array}$ & $\begin{array}{r}\text { Std. Error of } \\
\text { the Estimate }\end{array}$ & $\begin{array}{r}\text { Durbin-Watso } \\
\mathrm{n}\end{array}$ \\
\hline 1 & $.538(\mathrm{a})$ & .290 & .268 & .0480892 & \\
2 & $.612(\mathrm{~b})$ & .375 & .336 & .0458038 & 1.425 \\
\hline
\end{tabular}
a Predictors: (Constant), AUDITOR
b Predictors: (Constant), AUDITOR, NET ASSETS
c Dependent Variable: QUALITY OF DISCLOSURE

Table 6: ANOVA(c)

\begin{tabular}{|l|l|r|r|r|r|r|}
\hline \multirow{2}{*}{ Model } & & $\begin{array}{c}\text { Sum of } \\
\text { Squares }\end{array}$ & $\mathrm{df}$ & Mean Square & \multicolumn{1}{c|}{$\mathrm{F}$} & Sig. \\
\hline 1 & Regression & .031 & 1 & .031 & 13.457 & $.001(\mathrm{a})$ \\
& Residual & .076 & 33 & .002 & & \\
& Total & .107 & 34 & & & \\
& Regression & .040 & 2 & .020 & 9.604 & $.001(\mathrm{~b})$ \\
& Residual & .067 & 32 & .002 & & \\
& Total & .107 & 34 & & & \\
\hline
\end{tabular}
a Predictors: (Constant), AUDITOR
b Predictors: (Constant), AUDITOR, NET ASSETS
c Dependent Variable: QUALITY OF DISCLOSURE 


\section{Macrothink}

International Journal of Accounting and Financial Reporting ISSN 2162-3082 2013, Vol. 3, No. 2

Table 7:

Coefficients(a)

\begin{tabular}{|c|c|c|c|c|c|c|}
\hline \multirow[t]{2}{*}{ Model } & & \multicolumn{2}{|c|}{ Unstandardized Coefficients } & $\begin{array}{l}\text { Standardized } \\
\text { Coefficients }\end{array}$ & $\mathrm{t}$ & Sig. \\
\hline & & B & Std. Error & Beta & & \\
\hline \multirow[t]{2}{*}{1} & (Constant) & 0.9365 & 0.0196 & & 47.7021 & $5.05 E-32$ \\
\hline & AUDITOR & -0.0791 & 0.0216 & -0.5382 & -3.6684 & 0.0009 \\
\hline \multirow[t]{3}{*}{2} & (Constant) & 0.9325 & 0.0188 & & 49.6149 & $7.62 \mathrm{E}-32$ \\
\hline & AUDITOR & -0.0843 & 0.0207 & -0.5738 & -4.0759 & 0.0003 \\
\hline & NET ASSETS & 1.809E-07 & $8.65 \mathrm{E}-08$ & 0.2945 & 2.0917 & 0.0445 \\
\hline
\end{tabular}

a Dependent Variable: QUALITY OF DISCLOSURE

Therefore hypotheses; H2: Company size is positively associated with the quality of financial and non-financial statement disclosure. and H4: Auditor type is positively associated with the quality of financial statement disclosure, are accepted and the others cannot be accepted. The findings are consistent with earlier research by (Singhvi and Desai 1971; Ahmed and Nicolls 1994, Wallace and Naser 1995, Meek 1995, Inchausti1997; Dumontier and Raffournier 1998, Naser et al. 2002, Camfferman and Cooke 2002) who found similar results for compliance from companies in many countries.

\section{Table 8: Excluded variables}

Excluded Variables(c)

\begin{tabular}{|c|c|c|c|c|c|c|}
\hline Model & & Beta In & $\mathrm{t}$ & Sig. & $\begin{array}{l}\text { Partial } \\
\text { Correlation }\end{array}$ & $\begin{array}{l}\text { Collinearity } \\
\text { Statistics }\end{array}$ \\
\hline & & & & & & Tolerance \\
\hline \multirow[t]{4}{*}{1} & NET ASSETS & 0.2945 & 2.0917 & 0.0445 & 0.3468 & 0.9854 \\
\hline & $\begin{array}{l}\text { RETURN ON } \\
\text { EQUITY }\end{array}$ & 0.1246 & 0.8176 & 0.4196 & 0.1430 & 0.9358 \\
\hline & $\begin{array}{ll}\text { DEBT } & \text { EQUITY } \\
\text { RATIO } & \end{array}$ & -0.1226 & -0.8274 & 0.4142 & -0.1447 & 0.9901 \\
\hline & LIQUIDITY & -0.0085 & -0.0565 & 0.9553 & -0.0100 & 0.9875 \\
\hline \multirow[t]{3}{*}{2} & $\begin{array}{l}\text { RETURN ON } \\
\text { EQUITY }\end{array}$ & 0.1895 & 1.3015 & 0.2027 & 0.2276 & 0.9014 \\
\hline & $\begin{array}{ll}\text { DEBT } & \text { EQUITY } \\
\text { RATIO } & \end{array}$ & -0.0791 & -0.5501 & 0.5862 & -0.0983 & 0.9664 \\
\hline & LIQUIDITY & 0.0136 & 0.0948 & 0.9251 & 0.0170 & 0.9820 \\
\hline
\end{tabular}

a Predictors in the Model: (Constant), AUDITOR

b Predictors in the Model: (Constant), AUDITOR, NET ASSETS

c Dependent Variable: QUALITY OF DISCLOSURE 


\section{$\Lambda$ Macrothink}

International Journal of Accounting and Financial Reporting ISSN 2162-3082

The findings go on to support the idea that the size of a company's audit firm and its international link do influence the quality of information disclosed in the annual reports. Thus big companies audited by the big audit firms with international links do produce quality financial reports in accordance with IAS 1 and the IASB's qualitative characteristics of relevance, faithful representation, understandability and comparability. According to (Tasios and Bekiaris 2012,14) "auditors perceive qualitative characteristics as important quality factors of financial reports, considering faithful representation as the most important of them".

\section{Conclusion}

This study was conducted to investigate the quality of financial reports of firms listed on the Ghana Stock Exchange before and after adopting IFRS in Ghana. It also investigated the influence of firm-specific characteristics which include firm size, profitability, debt equity ratio, liquidity and audit firm size on quality of financial information disclosed by these listed firms.

The research was conducted through detailed analysis of the 2006 and 2008 financial statements of the listed firms. Descriptive analysis was performed to provide the background statistics of the variables examined. This was followed by regression analysis which forms the main data analysis. The results of the quality of financial information disclosure mean of $87.09 \%$ for year 2009 as against $76.8 \%$ for 2006 indicates significant improvement in the quality of financial reports after adopting IFRS in Ghana. It also indicates overwhelming compliance with the IASB's IFRS Framework. The study confirms that the implementation of IFRSs generally reinforce accounting quality. With the improvement in the quality of the financial reports after adopting IFRSs users are assured of useful information for financial decision-making.

The results of the multiple regression analysis shows that company size, represented by net assets and Auditor type were found to be statistically associated with the quality of financial information disclosed. This means that big firms audited by big audit firms tend to produce high quality accounting reports. Thus fulfilling the requirements of not only the qualitative characteristics of financial statements but also the tenets of agency theory. As a result of asymmetric information and self-interests, the principals (shareholders) should have reasons not to trust the agents (the managers). In this sense, certain mechanisms (auditors) are put in place to align the interests of agents with those of the principals, thus reducing the possibility of information asymmetry, as well as opportunistic behaviors (ICAEW, 2005).

This study contributes to the literature on corporate financial reporting and disclosure practices. The Ghana Stock Exchange is one of the important capital markets in the Africa, south of the Sahara, in which International Financial Reporting Standards (IFRSs) are mandatory. Therefore a study on the quality of financial report disclosure is significant. It also contributes to the literature on whether the company characteristics that researchers have found to be significant in companies in developed countries can be applied in a developing country like Ghana. This has been achieved as results are consistent with some of the research conducted in the developed economies. 


\section{Macrothink}

International Journal of Accounting and Financial Reporting ISSN 2162-3082 2013, Vol. 3, No. 2

One of the shortcomings of this work is the fact that it was limited to firms listed on the Ghana Stock Exchange. This makes it very difficult to generalize the findings. The researcher therefore, recommends that other researchers consider working with a bigger sample comprising some of the unlisted firms in Ghana.

\section{References}

Agyei-Mensah (2012). Association between firm-specific characteristics and the levels of disclosure of financial information of rural banks in the Ashanti Region of Ghana. Journal of Applied Finance \& Banking, vol.2, no.1, 69-92 ISSN: 1792-6580 (print version), 1792-6599 (online) International Scientific Press.

Ahmed, K. and Courtis, J. K. (1999), Association Between Corporate Characteristics and Disclosure Levels in Annual Reports: A Meta-Analysis, British Accounting Review, 132, 1: 3561.

Ahmed K, Des Nicolls (1994). "The Impact of Nonfinancial Company Characteristics on Mandatory Disclosure Compliance in Developing Countries: The Case of Bangladesh", International Journal of Accounting Education Research 29:6277.

Akhtaruddin, M. (2005). Corporate mandatory disclosure practices in Bangladesh. International Journal of Accounting, 40/4, 399-422.

Alsaeed, K. (2006). The association between firm-specific characteristics and disclosure. Managerial Auditing Journal, Vol. 21, pp. 476-496.

Al-Shammari, B. (2008). Voluntary disclosure in Kuwait corporate annual reports. Review of Business Research, 1, 10-30.

Baiman, S., and R. E. Verrecchia, (1993), The relation between capital markets and financial disclosure, Production Efficiency and Insider Trading, Journal of Accounting Research 34, $1-22$.

Barako, D.G (2007). Determinants of voluntary disclosures in Kenyan companies annual reports. African Journal of Business Management Vol. 1(5) pp. 113-128.

Camfferman, K., \& Cooke, T. E. (2002). An analysis of disclosure in the annual reports of UK and Dutch companies. Journal of International Accounting Research, 1(1), 3-30.

Cairns D (1997). Developing Countries always on the agenda. Accountancy 119(1244):62-63.

Cerf, A. R. (1961). Corporate reporting and investment decision. Berkeley: University of California Press.

Choi FDS (1973). Financial disclosure and entry to the European capital market. Journal of Accounting Research, 11(Autumn):159-175.

Cooke T (1989). Disclosure in the corporate annual reports of Swedish companies. Accounting Business Research 19:113-124. 


\section{Macrothink}

International Journal of Accounting and Financial Reporting ISSN 2162-3082

Cooke T (1991). An assessment of voluntary disclosure in annual reports of Japanese corporations. International Journal of Accounting 26(3):174-189.

Cooke T (1993). Disclosure in Japanese Corporate Reports. Journal of Business Finance and Accounting 20(4):521-535.

Cooke TE (1992). The Impact of Size, Stock Market Listing and Industry Type on Disclosure in the Annual Reports of Japanese Listed Corporations. Accounting \& Business Research 22(87):229-37.

Cooke TE (1998). Regression Analysis in Accounting Disclosure Studies. Accounting \& Business Research 28(3):209-224.

Dahawy, K. (2009), Company characteristics and disclosure level: The case of Egypt. International Research Journal of Finance and Economics, issue 34.

Dahawy, K. (2007), Accounting disclosure in companies listed on the Egyptian Stock Exchange, Middle Eastern Finance and Economics. Issue 1 .

Dahawy, K., Merino, B.D. and Conover, T.L. (2002) The conflict between IAS disclosure requirements and the secretive culture in Egypt, Advances in International Accounting, 15, pp. 203-28.

El-Gazzar S, Finn P, Jacob R (1999). An empirical investigation of multinational firms' compliance with International Accounting Standards". International Journal of Accounting. 34(2):239-248.

Dumontier P, Raffournier B (1998). Why firms comply voluntarily with IAS: An empirical analysis with Swiss data. Journal of International Financial Management \& Accounting 9:216-245.

Fekete, et al. (2008) Determinants of the Comprehensiveness of Corporate Internet Reporting by Romanian Listed Companies, working paper presented in AMIS 2008 conference in Bucharest.

Ghazali, N.A.M., \& Weetman, P. (2006). Perpetuating traditional influences: Voluntary disclosure in Malaysia following the economic crisis. Journal International Accounting Auditing \& Taxation. Vol.4, No.2, pp.226-248

Gibbins M., A. Richardson, and J. Waterhouse. (1990). “The Management of Corporate

Financial Disclosures: Opportunism, Ritualism, Policies and Processes." Journal of Accounting Research, 28(1), 121-143.

Giordano-Spring, S., and J.-N. Chauvey. (2007). Assessing the quality of corporate social reporting through Reporting Principles: An empirical study of French listed companies on SBF 120 Stock Index. European Accounting Association Annual Conference. Lisbon, Portugal.

Haneh, A.M.A (2009), Association between Firm-Specific characteristics and voluntary 
disclosure of listed companies in Kuwait. A Masters' thesis submitted to University of Utara Malaysia.

Haniffa, R. M. and Cooke, T. E. (2002), Culture, Corporate Governance and Disclosure in Malaysian Corporations, Abacus, 38, 317-349.

Hossain M, Tan LM, Adams M (1994). "Voluntary Disclosure in an Emerging Capital Market: Some Empirical Evidence from Companies Listed on the Kuala Lumpur Stock Exchange”. International Journal of Accounting 29:334-351.

IASB (2010). The Conceptual Framework for Financial Reporting, London.

Iatridis, G., and Valahi, S (2010) Voluntary IAS 1 accounting disclosures prior to official IAS adoption: An empirical investigation of UK firms. Research in International Business and Finance, 24, 1-14.

ICAEW (2005). Information for Markets and Society. Institute of Chartered Accountants England and Wales, London.

Inchausti, B. (1997). The influence of company characteristics and accounting regulations on information disclosure by Spanish firms. European Accounting Review, 6, 45-68.

Jaggi B, Low P (2000). Impact of Culture, Market Forces, and Legal System on Financial disclosures. International Journal of Accounting. 35(4):459-519.

Jensen, M. and Meckling, W. (1976). Theory of the Firm: Managerial Behavior, Agency Costs and Ownership Structure, Journal of Financial Economics, 3, 3 (October): 306-60.

Malone D, Fries C, Jones T (1993). An empirical investigation of the extent of corporate financial disclosure in the oil and gas Industry. Journal of Accounting, Auditing \& Finance. $8(3): 249-273$

Marston C, Robson P (1997). Financial reporting in India: Changes in disclosure over the period 1982 to 1990. Asia-Pacific Journal of Accounting. 4(6):109-139.

Owusu-Ansah S (1998). The impact of corporate attributes on the extent of mandatory disclosure and reporting by listed companies in Zimbabwe. International Journal of Accounting. 33(5): 605-631.

Percy, Majella. (2000). Financial reporting discretion and voluntary disclosure: corporate research and development expenditure in Australia. Asia-Pacific Journal of Accounting \& Economics, 7(1): 1-31.

Raffournier B (1995). The determinants of voluntary financial disclosure by Swiss listed companies. European Accounting Review 4(2):261-280

Sloan, R.G. (2001), Financial accounting and corporate governance: a discussion, Journal of Accounting and Economics, Vol.32 No.1-3, December, p 335-347.

Street DL, Bryant S (2000). Disclosure level and compliance with IASs: A comparison of companies with and without U.S. listings and fillings. International Journal of Accounting. 


\section{Macrothink \\ International Journal of Accounting and Financial Reporting \\ ISSN 2162-3082 2013, Vol. 3, No. 2}

35:305-329.

Street DL, Gray S (2001). Observance of international accounting standards: Factors explaining non-compliance, ACCA Research Report No. 74, The Association of Chartered Certified Accountants. London, UK.

Tasios, S. and Bekiaris, M. (2012). Auditor's perceptions of financial reporting quality: the case of Greece. International Journal of Accounting and Financial Reporting 2(1): 57-74.

Tower G, Hancock P, Taplin R .H (1999). A regional study of listed companies' compliance with international accounting standards. Accounting Forum 23(3):293-305.

Verrecchia, R. (2001). Essays on disclosure. Journal of Accounting and Economics, v. 22, p.97-180.

Wallace, R.S.O. and Naser, K. (1995). Firm specific determinants of the comprehensiveness of mandatory disclosure in the corporate annual reports of firms listed on the stock exchange of Hong Kong. Journal of Accounting \& Public Policy, Vol. 14, pp. 311-68.

Wallace RSO (1988). Corporate financial reporting in Nigeria. Accounting \& Business Research. 18(72):352-362.

Wallace RSO, Naser K, Mora A (1994). The relationship between the comprehensiveness of corporate annual reports and firm specific characteristics in Spain. Accounting \& Business Research. 25(97):41-53.

World Bank (2005). Report on Observance of Standards and Codes, Ghana. World Bank, 2008.

Zarzeski, M.T. (1996). Spontaneous harmonization effects of culture and market forces on accounting disclosure practices. Accounting Horizons, March, pp.18-38.

Appendix 1: - Operational measures utilized for the qualitative characteristics [(Adapted from Beest, F.V., Braam, G., and Boelens, S. (2009)].

\section{Relevance}

R1 The annual reports discloses forward-looking information

R2 The annual reports discloses information in terms of business opportunities and risks

R3 The company uses fair value as measurement basis

R4 The annual report provides feedback information on how various market events and significant transactions affected the company?

Relevance total score (4) 


\section{Macrothink \\ International Journal of Accounting and Financial Reporting \\ ISSN 2162-3082 2013, Vol. 3, No. 2}

\section{Faithful representation}

F1 The annual report explains the assumptions and estimates made clearly

F2 The annual report explains the choice of accounting principles clearly

F3 The annual report highlights the positive and negative events in a balanced way when discussing the annual results

F4 The annual report includes an unqualified auditor's report

F5 The annual report extensively discloses information on corporate governance issues

Faithful representation total score (5)

\section{Understandability}

U1 The annual report is a well organized

U2 The notes to the balance sheet and the income statement are clear

U3 Graphs and tables clarify the information presented

U4 The use of language and technical jargon is easy to follow in the annual report

U5 The annual report included a comprehensive glossary

\section{Understandability total score (5)}

\section{Comparability}

C1 The notes to changes in accounting policies explain the implications of the change

$\mathrm{C} 2$ The notes to revisions in accounting estimates and judgments explain the implications of the revision

C3 The company's previous accounting period's figures are adjusted for the effect of the implementation of a change in accounting policy or revisions in accounting estimates.

C4 The results of current accounting period are compared with results in previous accounting periods

C5 Information in the annual report is comparable to information provided by other organizations

C6 The annual report presents financial index numbers and ratios

Comparability total score $=(6)$ 